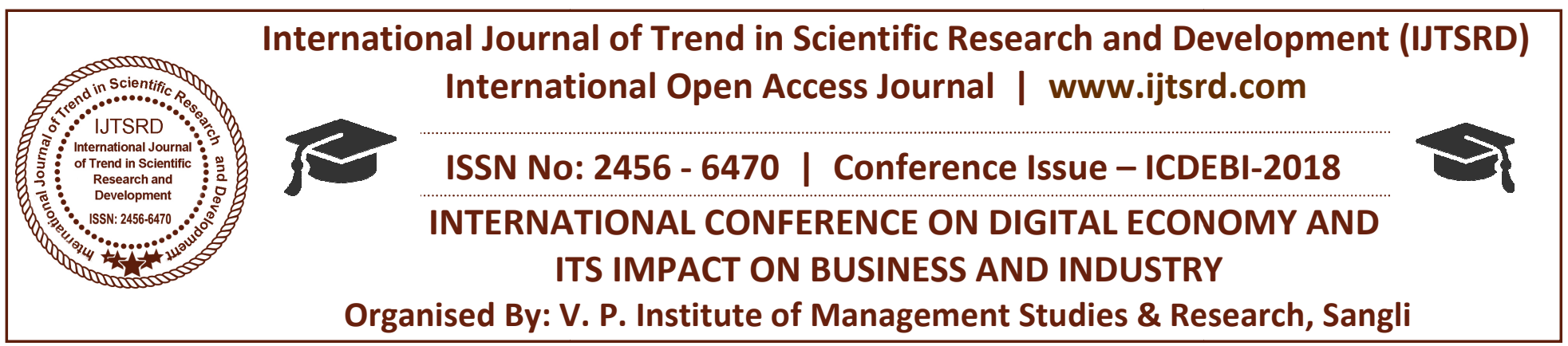

\title{
An Empirical Study of IPPB with Reference to its Vision and Mission Statement
}

\author{
Mr. Bharat Nagargoje ${ }^{1}$, Mrs. Saba A.S. ${ }^{2}$ \\ ${ }^{1}$ Assistant Professor, Indira College of Commerce \& Science, Tathewade, Pune, Maharashtra, India \\ ${ }^{2}$ Assistant Professor, VPIMSR, Sangli, Maharashtra, India \\ Affiliated to Shivaji University, Kolhapur, Maharashtra, India
}

\section{ABSTRACT}

On 19 August 2015 RBI has issued the license to India Post to run a payments bank. On 17 August 2016, IPPB was registered as a public limited government company for setting up a payments bank. India Post Payments Bank (IPPB) was setup under the Department of Posts, Ministry of Communication with $100 \%$ equity owned by Government of India. On 17th August 2016 it has been registered as a public limited government company. There are 155,015 post offices and 400,000 postal service workers who are going to provide house to house banking services. The Pilot project was launched in Ranchi (Jharkhand) and Raipur (Chhattisgarh) on 30 January 2017. IPPB will expand in phases across India covering all post offices, through a network of DIPPB branches/controlling offices, working on a hub and spoke model. The first phase nationwide inauguration happened on September 1, 2018 with 650 branches and 3250 post offices as access points.

The IPPB has the vision of 'Building the most accessible, affordable and trusted bank for the common man.' and the mission is 'Spearheading financial inclusion by removing barriers and reducing costs for accessing banking services.' This paper is intended to analyze the policies of IPPB to check its alignment with the abovementioned mission and vision of the bank.

KEYWORDS: Payment Bank, Digitization, Indian Economy, India Post, Doorstep Banking, QR Card

\section{INTRODUCTION}

In September 2013, the Reserve Bank of India constituted a committee headed by Dr. Nachiket Mor to study 'Comprehensive financial services for small businesses and low income households'. The objective of the committee was to propose measures for achieving financial inclusion and increased access to financial services. The committee submitted its report to RBI in January 2014. One of the key suggestions of the committee was to introduce specialized banks or 'payments bank' to cater to the lower income groups and small businesses so that by January 1, 2016 each Indian resident can have a global bank account.

Payment bank is the new type of bank which has been approved by the RBI and the Government of India. Reserve Bank of India gave its in-principle approval for the new kind of banks called as Payments Bank. There are 6 banks which received such license. Currently four banks out of six are caring their transactions. The A payments bank is the small version of the existing banks with the deposit limit of Rs. 1 lakh. These banks are not allowed to issue the cheque book facility to the customers. The payment bank can't advance loans or credit to its customers. The bank can offer the facilities like remittance of funds, Internet banking, bill payments, recharges and other banking facility except the loans and advances.

The main objective of payments bank is the spread of payment and financial services to small business, lowincome households, and migrant labour workforce with the help of the technology and internet. The payment bank enables to increase the level of use of financial services to the remote areas of the country. 
India Post Payments Bank (IPPB) is set up by the Department of Posts, Ministry of Communication, and Government of India. This bank has been established to utilize the huge network of India post and the postmen to provide house to house banking services. All 3 lakh postmen and gramindaksevaks will be equipped with mobile devices and will increase the customer base with the help of 1.55 lakh India Post offices across the country which is nearly 2.5 times of the bank network. The post payments bank has an advantage to link all its 17 crore post office savings bank accounts. ${ }^{4}$

Apart from the all other facilities of payments bank, IPPB provides a QR Code-based biometric card to its customers. The bank also provides the facility of sweep the balance between the IPPB saving account and the post saving bank account. This will help customer to maintain the balance of more than Rs. 1 lakh which is the maximum limit of deposit set for the payment bank.

\section{Unique Services offered by IPPB:}

QR Card: It provides a unique, secure and convenient way to access bank account. Customer is not required to remember PIN/Password, as transactions can be initiated by using biometric authentication. Customers can perform cash transactions, money transfer, bill payments, or cashless shopping using this card. To perform any transaction, customer simply has to scan the $\mathrm{QR}$ code on the card and authenticate it through biometric verification.

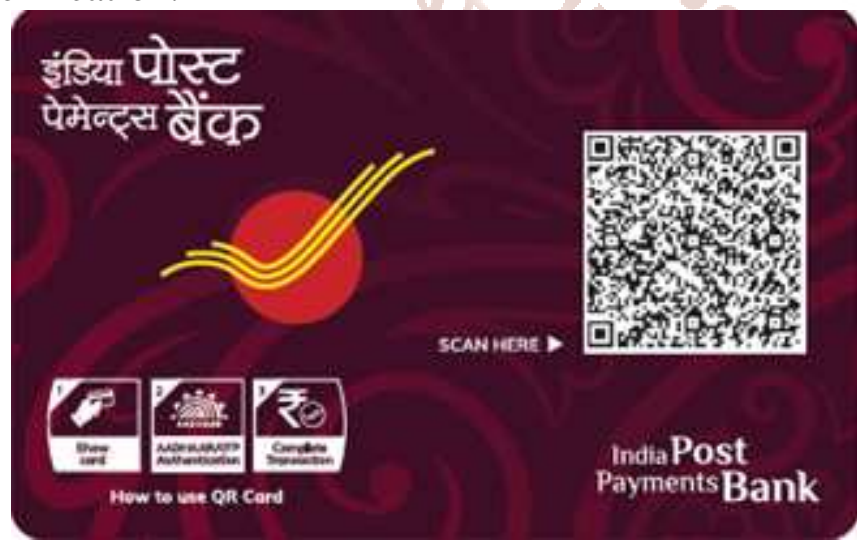

Doorstep Banking: IPPB provides the opportunity to enjoy banking facilities at home with Doorstep banking services. The wide network of post offices and postal employees will make banking accessible to the remotest corners of the nation. This facility enables to open a bank account, transfer funds, deposit and withdraw cash, recharge or pay bills and accomplish much more by a trusted GDS/Postman at the customers home or office premises This helps to save time, effort and cost of travelling to the bank.

SWEEP facility: The RBI has permitted IPPB to link the Post office saving account. There are more than 17 Crore of such accounts which could be linked with the IPPB account. As the payment bank has the permission to accept the deposit of Rs. 1 lakh per account, the excess balance can be swept to the linked POSA account.

\section{Literature Review:}

The bank is providing various services including Mobile banking, Phone banking, SMS banking, missed call banking etc. Bank also provides the various payment services. The unique feature of the bank includes the doorstep banking and use of QR Card. ${ }^{1}$

Financial Inclusion is "The process of ensuring access to financial services and timely and adequate credit where needed by vulnerable groups such as weaker sections and low income groups at an affordable cost" (Rangarajan Committee, 2008).

The department of post is financially not in good condition. It has the deficit of 119.69 billion in the year 2016-17. As the beacon of inclusive banking, it appears that the choice of IPPB is seems to be incorrect. $^{2}$

One of the key suggestions of the committee on financial inclusion was to introduce specialized banks or 'payments bank' to cater to the lower income groups and small businesses so that by January 1, 2016 each Indian resident can have a global bank account. $^{3}$

\section{Objectives:}

1. To analyze the services provided by India Post Payments Bank

2. To check the compatibility of the services provided by the bank with the Vision and Mission statement of the bank.

\section{Data Collection:}

The secondary data has been collected from the banks official website, different articles from internet and the newspaper. 
Data collection and Interpretation:

Services offered by the bank:

\section{Saving Account:}

Bank provides saving account in 3 different variants i.e. Regular saving account, Digital saving account and Basic saving account.

The Regular saving account is the Zero balance account with Interest rate of $4 \%$ p.a. This account also provides the facility of fund transfer through IMPS and the facility of Bill payments and recharges. The unique feature of the account is the use of $\mathrm{QR}$ card and the facility to link POSA (Post Office Saving Account). As the deposit limit of Rs. 1 Lakh is applicable to the payment bank, the balance above 1 lakh automatically gets swept in to linked POSA

The charges applicable to the various services vary from 0 to 50. There are no charges for deposits and withdrawal, but there is the limit on the amount from Rs. 5,000 to 20,000. There are charges for each transaction for the doorstep facility. The bank also charges the fees for the fund transfer. These charges vary from Rs. 2.5 to 50 per transaction per customer.

The digital saving account is the Digital version of the regular saving account. This account can be opened and operated through the IPPB Mobile App and Android Phone. The basic saving account is also bundled with the same services like regular saving account.

Analysis: Except the doorstep banking service, there is no other service which provides the competitive advantage to attract the new customers. In fact other payment banks like Paytm gives $6 \%$ rate of interest and free fund transfer services.

\section{Current Account:}

IPPB offers the facility of a Current Account to the small merchants/ kirana stores and individual businessmen. The minimum monthly balance required for this account is Rs. 1,000. The cheque collection charges of Rs 25 to 200 per instrument based on the amount. There are also the charges on cash Deposits above Rs 15,000 per day.

Analysis: The maximum limit of Rs 1 lakh on the account balance, and the charges on the deposit over Rs. 15,000 per day, indicates that the account is not likely to be preferred by the businessmen.
Mobile Banking, Phone Banking, SMS banking and missed call banking:

Through Mobile banking, IPPB provides the facility to operate the bank account on android mobiles. The customer can do almost all the transactions using the IPPB Mobile App. The transactions like Balance and statement enquiry, fund transfer, bill payments, cheque book request, stop payment request and sweep funds etc. can be carried using the mobile banking.

In Phone banking, there is no requirement of having Android mobile with internet connection to use these services. Except Fund transfer and the Sweep funds, all other transactions can be done using Phone banking

SMS banking and missed call banking is used only for the balance enquiry and Mini statement.

Analysis: It seems that IPPB is in line with all other banks in providing these services. The only advantage to the bank seems here that the postmen can be the key factor to guide the customers to use these facilities.

\section{QR Card and Biometric authentication:}

IPPB is not providing the normal debit card to its customer instead it provides $\mathrm{QR}$ card which depends on the Biometric authentication. For this authentication it uses the ADDHAR database. UIDAI has told to Supreme Court that it cannot insure $100 \%$ biometric matching. In this context if the fingerprint prints doesn't match the customer cannot perform any transaction.

\section{Vision and Mission statement of IPPB:}

The Bank has been established with the Vision of 'Building the most accessible, affordable and trusted bank for the common man.' This vision has backed by the existing network of the postmen. The postmen is the most accessible and trusted person for the common man in rural India. The same postmen are going to play an important role as a banker to achieve this vision of the bank.

The bank has formed a Mission of 'Spearheading financial inclusion by removing barriers and reducing costs for accessing banking services.' to achieve its vision. The financial inclusion is depends on role played by the postmen in opening the new accounts. Also the 17 crore Post office saving accounts can be linked to the IPPB account which will provide the 
readymade customer base to the bank to achieve the mission of financial inclusion.

Comparison of the banking services with the Vision and mission statement:

\begin{tabular}{|c|c|c|}
\hline $\begin{array}{l}\text { The vision / mission component to } \\
\text { be achieve }\end{array}$ & Favourable policies & Adverse Policies \\
\hline Most accessible Bank & Doorstep Banking. & \\
\hline Most affordable Bank & & $\begin{array}{c}\text { There are charges for almost all } \\
\text { transactions. }\end{array}$ \\
\hline Most Trusted Bank & $\begin{array}{l}\text { A postman's personal } \\
\text { bonding. }\end{array}$ & \\
\hline Spearheading financial inclusion & $\begin{array}{l}17 \text { Crore POSA can be } \\
\text { linked. }\end{array}$ & Difficult to reach to Urban customers. \\
\hline $\begin{array}{l}\text { removing barriers in accessing } \\
\text { banking services }\end{array}$ & Biometric authentication. & \\
\hline $\begin{array}{c}\text { Reducing cost of Accessing banking } \\
\text { services }\end{array}$ & 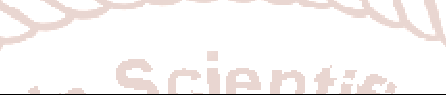 & $\begin{array}{l}\text { High charges compare to other } \\
\text { payment banks. }\end{array}$ \\
\hline
\end{tabular}

\section{Findings and suggestions:}

From the above analysis of the services provided by IPPB, it seems that various policies related to the charges and the limits on the transitions are high and rigid in comparison to other payment banks. Hence we can say that in the long run, bank has to revise the charges on the transaction to achieve the quality of 'affordable' in its Vision statement.

The service like Doorstep banking using the network of the Postmen, indicate that bank is in line with its vision of becoming most accessible and trusted bank.

\section{Conclusion:}

The one thing which is not measured or analyzed it the potential of the strong bonding of the Postmen with almost all the villagers, farmers and the rural craftsmen. With the help of this potential, and the banking skills the postmen can be a game changer. In spite of all other drawbacks like the use of only $Q R$ cards, charges on the transactions, and the competition by the other banks, IPPB will attract and retain the new customers. If this happens then we can say that IPPB has achieved its mission of Spearheading financial inclusion.

\section{REFERENCES}

1. The official website of IPPB: https://ippbonline.com/web/ippb/vision-mission

2. India Post payment Bank's problems of plenty: the article in the Business standard, 06/09/2018

3. "Committee on Comprehensive Financial Services for Small Businesses and Low Income Households" Dr. Nachiket Mor, Central Board Member, Reserve Bank of India, January 2014

4. Times of

Indi: https://economictimes.indiatimes.com/definition/p ayments-banks 